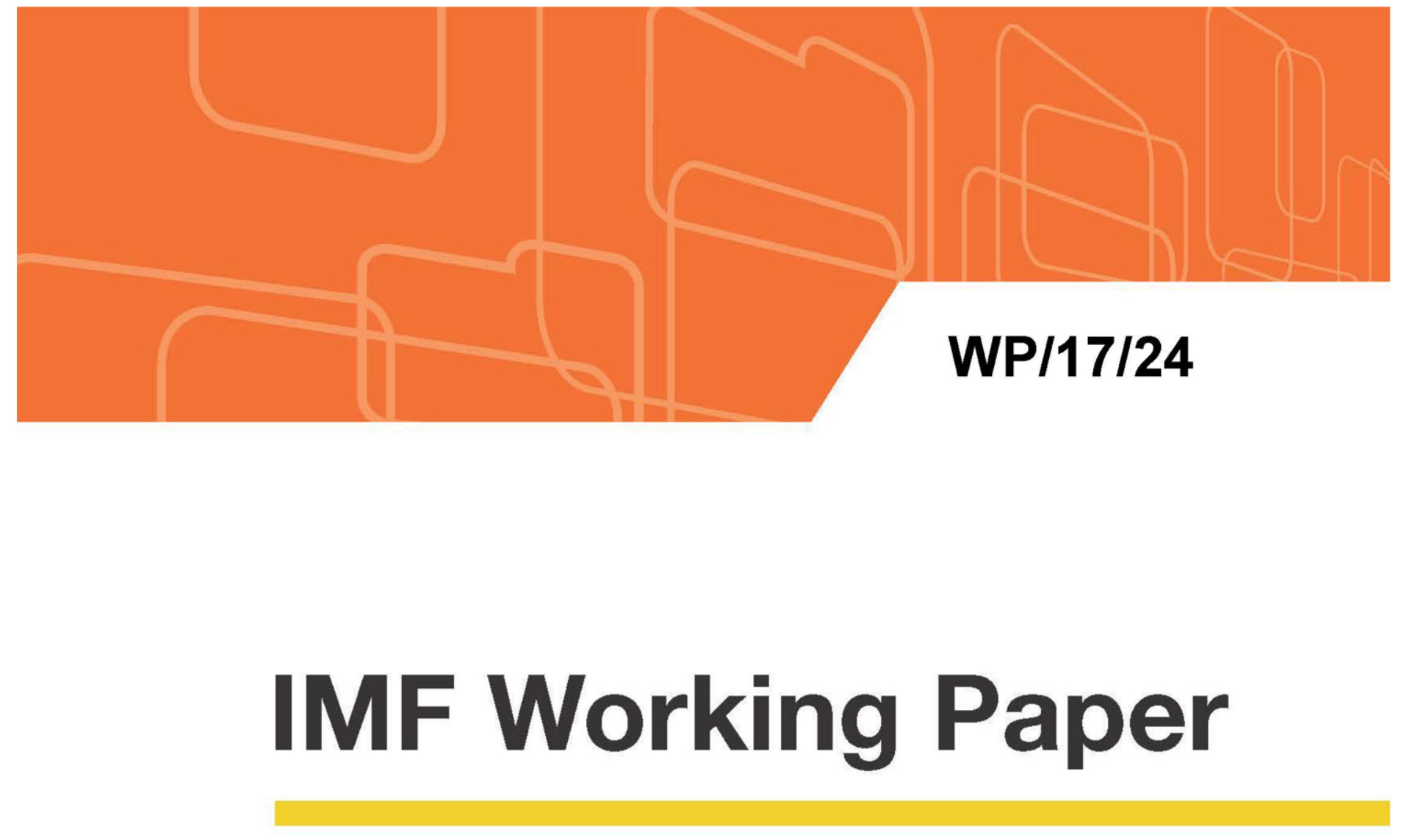

\title{
Banks' Adjustment to Basel III Reform: A Bank-Level Perspective for Emerging Europe
}

by Michal Andrle, Vladimír Tomšík, and Jan Vlček

IMF Working Papers describe research in progress by the author(s) and are published to elicit comments and to encourage debate. The views expressed in IMF Working Papers are those of the author(s) and do not necessarily represent the views of the IMF, its Executive Board, or IMF management. 


\section{WP/17/24}

\section{IMF Working Paper}

\section{Banks' Adjustment to Basel III Reform: A Bank-Level Perspective for Emerging Europe}

by Michal Andrle, Vladimír Tomšík, and Jan Vlček

IMF Working Papers describe research in progress by the author(s) and are published to elicit comments and to encourage debate. The views expressed in IMF Working Papers are those of the author(s) and do not necessarily represent the views of the IMF, its Executive Board, or IMF management. 


\title{
IMF Working Paper
}

Research Department

\section{Banks' Adjustment to Basel III Reform: A Bank-Level Perspective for Emerging Europe ${ }^{1}$}

\author{
Prepared by Michal Andrle, Vladimír Tomšík, Jan Vlček
}

Authorized for distribution by Ben Hunt

February 2017

IMF Working Papers describe research in progress by the author(s) and are published to elicit comments and to encourage debate. The views expressed in IMF Working Papers are those of the author(s) and do not necessarily represent the views of the IMF, its Executive Board, or IMF management.

\begin{abstract}
The paper seeks to identify strategies of commercial banks in response to higher capital requirements of Basel III reform and its phase-in. It focuses on a sample of nine EU emerging market countries and picks up 5 largest banks in each country assessing their response. The paper finds that all banking sectors raised CAR ratios mainly through retained earnings. In countries where the banking sector struggled with profitability, banks have resorted to issuance of new equity or shrunk the size of their balance sheets to meet the higher capital-adequacy requirements. Worries echoed at the early stage of Basel III compilation, namely that commercial banks would shrink their balance sheet by reducing their lending to meet stricter capital requirements, did materialize only in banks struggling with profitability.
\end{abstract}

JEL Classification Numbers: G21, G28, E58

Keywords: capital adequacy, Basel III, balance sheet

Author's E-Mail Address: mandrle@,imf.org, jan.vlcek@cnb.cz, vladimir.tomsik@cnb.cz

\footnotetext{
${ }^{1}$ We would like to thank Ben Hunt for excellent comments and suggestions.
} 


\section{Contents}

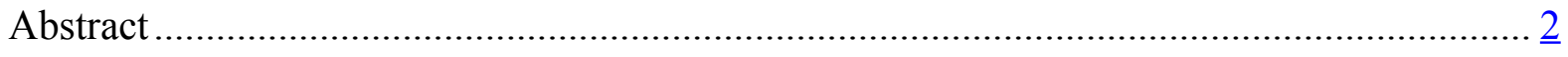

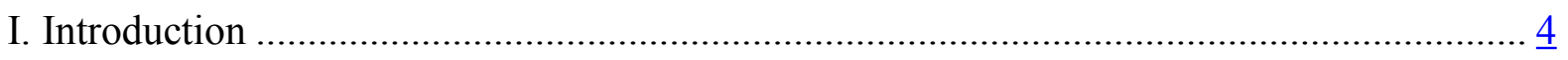

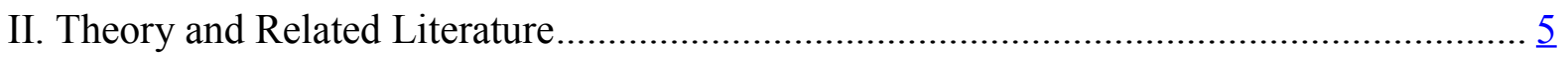

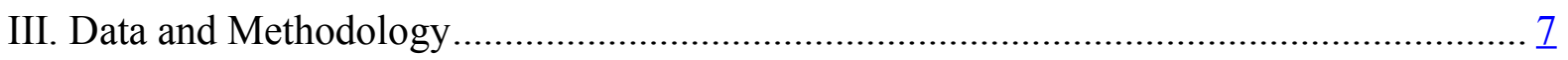

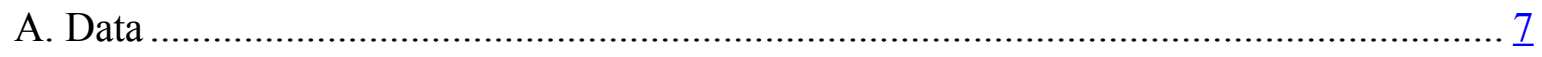

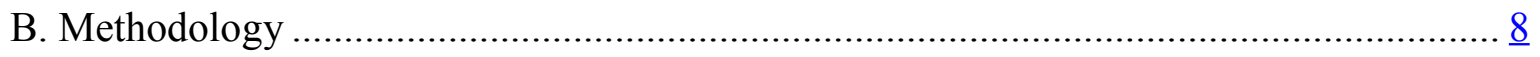

IV. Capital Adequacy Ratio Dynamics and Adjustment Strategies ...................................... 10

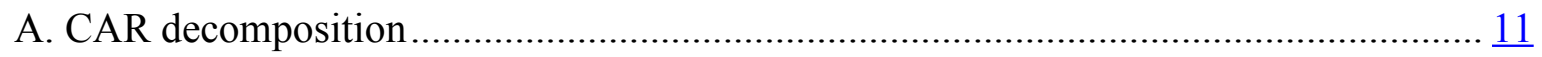

B. Decomposition of equity accumulation................................................................. 12

C. Decomposition of Net Income ……………………......................................... 13

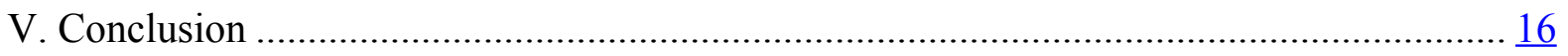

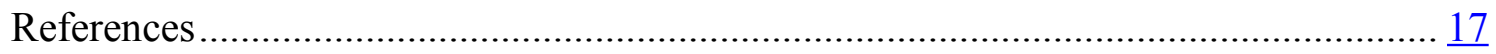

A. Appendix: Capital Accumulation Decomposition ………………………………… 19

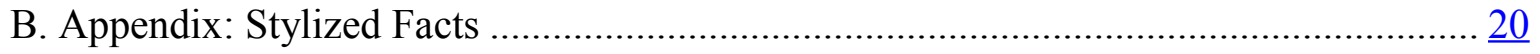

C. Appendix: The Leverage Arithmetic...................................................................... 23

1) Weighted Average Cost of Capital (WACC) under deviation from MMT .......... $\underline{23}$

2) Leverage hurts in bad times but helps in good times ......................................... $\underline{23}$

Table 1: Macroeconomic costs of higher capital requirements (Roger and Vlcek, 2011)...... 7 


\section{INTRODUCTION}

Basel III regulatory reform has been relying on higher capital quality and higher capital ratios as one of the key prudential tool. However, since the early debates there have been concerns about the size of the potential macroeconomic costs. The concerns have stemmed from a possibility that banks would meet the increased capital-adequacy requirements either by widening spreads between lending and deposit rates in order to boost net income or by reducing assets and loans. Both strategies could result in a credit slowdown, with adverse effects on real economic activity. Similar concerns might echo in the future when a nonzero countercyclical capital buffer is applied.

Banks can cope with higher capital-adequacy requirements in multiple ways and the structure of adjustment matters for the macroeconomic costs. In this regard, it is worth inspecting commercial banks' strategies for meeting the higher Basel-III capital requirements. The paper assesses strategies used by banks to meet new regulatory requirement. It does not evaluate macroeconomic costs given the challenges. Ex-ante, the evaluation would be subject to model uncertainty as it relies mostly on economic theory and structural economic models. Ex-post, empirical assessments are and will be complicated by the identification difficulties and data problems. In particular, the implementation of new Basel-III rules is directly related to the Global Financial Crisis, which has been followed by de-leveraging efforts of households and non-financial corporations. As such, quantification of the effects based on macro-econometric models is fraught with hazards and so bank-level analysis is an attractive alternative.

Given the progress of the reform, this paper seeks to assess how commercial banks in EU emerging-market countries met the tighter regulatory measures introduced with the start of the world financial crisis. We use data for five largest banks in each of the countries selected: Bulgaria, the Czech Republic, Hungary, Latvia, Lithuania, Poland, Romania, Slovakia, and Slovenia. Our paper assesses how the banks reacted to capital requirements and possible implications for macroeconomic costs of the adjustment.

The paper concludes that most of the banks in the EU emerging-market countries have used their retained earnings to increase their capital adequacy ratios. As deadly as leverage can be in a downturn, in better times it facilitates return on equity, easing a buildup of equity out of retained earnings. The accumulation of capital through retained earnings is considered a benign strategy of capital accumulation from a macroeconomic perspective. In countries where the banking sector has struggled with profitability, banks have resorted to the issuance of new equity or shrunk the size of their balance sheets, mainly by lending less, to meet the higher capital-adequacy requirements.

The paper is organized as follows. We briefly discuss the literature on this topic in the next section. The third section presents our methodology and framework. We assess the capital accumulation of banks in emerging market economies in the fourth section. 


\section{TheORY AND RELATED Literature}

\section{Based on mainstream economic theory, the result that increased capital-adequacy requirement should lead to sizeable macroeconomic costs is questionable. First, there is} an extensive literature building on the Modigliani-Miller Theorem (henceforth MMT) of capital structure irrelevance and corporations' valuation as articulated in Modigliani and Miller (1958, 1961, and 1963). MMT states that under the assumption of efficient markets an increase in the share of equity relative to liabilities lowers the riskiness of the bank. As a result, the cost of equity is lower for the bank, preserving the total cost of liabilities. In other words the debt-equity ratio of a bank should not affect its market value. Second, when assessing costs of regulation, we need to take into account the public benefits of the new regulation to properly assess its effects, as discussed at length in Admati and Hellwig (2013) and in Admati and others (2013).

Advanced and emerging economies should be examined separately because there could be important differences in the depth and effectiveness of the financial systems in the two groups. In fact, not all assumptions of MMT may hold and, perhaps, in emerging economies the deviations from MMT may be larger than in advanced economies. Therefore, we focus on emerging countries in contrast to other work. Despite all issues, we consider MMT a useful point even for these countries given that the corporate finance theory is built on the same arbitrage principles and it is used in valuation and risk analysis. ${ }^{2}$

There are several papers assessing the costs of higher capital requirements. Kashyap and others (2010) use a panel of US publicly-traded banks from 1976-2008 to assess how the riskiness of the bank varies with the level of capitalization. Their results are statistically significant and broadly in line with the predictions of MMT. ${ }^{3}$ They compute that a tenpercentage-point increase in the capital-adequacy requirement would increase the weightedaverage cost of capital by about 25 basis points (bp), or up to $45 \mathrm{bp}$ using rather extreme assumptions. This is a steady-state result; the authors pointed out that the transition path may be more costly and argued for a gradual phase-in of the Basel III rules. Estimates of Miles and others (2013) for the United Kingdom suggest that if leverage falls by half, the weighted average cost of capital increases by $18-33$ bp. ${ }^{4}$

\footnotetext{
${ }^{2}$ MMT and the conditions under which it holds are important for understanding why financial markets may deviate from this theorem. The key assumptions are efficient financial markets, and the absence of cost of bankruptcy and tax-code frictions, for instance, the preferential treatment of debt to equity. Much of the corporate finance after 1960s is about relaxation of the assumptions of the theorem and investigating the implications, see Stiglitz (1973).

${ }^{3}$ According to the basic version of the theory, if the equity ratio is doubled, the Capital Asset Pricing Model (CAPM) "beta" of the firm should fall by half.

${ }^{4}$ See Appendix for an example of the weighted-average cost of capital (WACC) calculation without MMT holding
} 
In the process of designing Basel III rules, Macroeconomic Assessment Group (2010) and Basel Committee on Banking Supervision (2010) carried out an ex-ante assessment of higher capital standards. Both studies assumed that the bulk of adjustment in capital ratios would go mainly through lending spreads without a change in the required return on equity. The Macroeconomic Assessment Group (2010) concluded that a 1 percentage point (pp) increase in capital ratios over 4 years would raise interest rate spreads by around $15 \mathrm{bp}$, pushing down lending volume by approximately 1.5 percent. As a result, real GDP declines by about 0.2 percent from the baseline path at the trough. Basel Committee on Banking Supervision (2010) estimated that a $1 \mathrm{pp}$ increase in capital implies higher spreads by 13 bp in the long run, leading to 0.1 percent decline in the output level compared to the baseline.

As a part of Macroeconomic Assessment Group (2010), Roger and Vlcek (2011) reached similar conclusions about modest macroeconomic impacts of Basel III. However, they emphasized that macroeconomic costs vary with different strategies of adjustment to higher capital standards. The study suggested that the lowest private macroeconomic costs are incurred if capital is raised by retaining earnings through a lower dividend payout ratio. Using a calibrated general-equilibrium model, the adjustment is found by Roger and Vlcek (2011) as the most benign strategy with respect to real growth. On the contrary, if banks raise capital by widening lending spreads, the estimated macroeconomic costs increase by roughly one half. The most costly means of raising capital ratios was found to be through adjustment in the level of assets. Reducing banks assets more than doubles the macroeconomic costs compared to the strategy based on a lower dividend payout ratio. The study conjectures that such a strategy is most likely to be adopted by banks when a very rapid adjustment in the capital ratio is required. Moreover, the authors also found that the cost of adjustment is much less if cuts in lending are to the riskiest clients. The findings of Roger and Vlcek (2011) are presented in Table 1. The study evaluates only costs, not the benefits which could overweight the costs in the long run.

The ongoing Basel III reforms allow us to evaluate bank adjustment strategies ex-post. Cohen (2013) and Cohen and Scatigna (2014) assessed the bank capital accumulation strategies in 2008 - 2012. They focus on 94 of the world's largest banks. They found that these banks used mainly retained earnings to meet higher regulatory standards. Both, wider lending spreads and lower dividend payouts helped to create enough retained earnings. Furthermore, Cohen and Scatigna (2014) shows that on average banks continued to expand their lending and there was a lesser role of bank assets riskiness reduction. As a result, the findings of their study do not support the initial concern that banks cut lending in response to higher capital requirements.

Our paper discusses the bank-level adjustment in the EU emerging-market countries building on and extending the analysis of Cohen and Scatigna (2014). We use accounting data for individual banks and decompose the cumulative change in the ratio of capital to riskweighted assets, equity growth, and dynamics of net income. There are some key stylized facts on banks in the EU emerging-market countries. First, these banks are small measured by the world-asset-size ranking. Second, most of them are subsidiaries with a parent in an advanced country. Third, the banks were not initially under pressure with respect to Basel III regulation. All banks in our sample had a CAR above the 8 percent regulatory minimum in 
2008. Furthermore, 29 banks out of 38 in our sample had a CAR above 10.5 percent ( 8 percent as regulatory minimum and 2.5 percent as a conservation buffer). However, banks in Baltic countries, Hungary and Slovenia, faced profitability and solvency issues in the 2008 2014 period.

Table 1: Macroeconomic costs of higher capital requirements (Roger and Vlcek, 2011)

\begin{tabular}{llcccc}
\hline & & \multicolumn{2}{c}{ Scenario } \\
\cline { 3 - 6 } & & $\begin{array}{c}\text { Dividend } \\
\text { policy and ROE }\end{array}$ & $\begin{array}{c}\text { Lending } \\
\text { spreads }\end{array}$ & \multicolumn{2}{c}{ Reducing banks assets } \\
\cline { 5 - 6 } & & & 60 & $\begin{array}{c}\text { LTV ratio and } \\
\text { Riskiness changed }\end{array}$ & $\begin{array}{c}\text { LTV ratio } \\
\text { changed by 1 p.p }\end{array}$ \\
\hline Peak lending spread (basis points) & Euro Area & 50 & 70 & 13 & 60 \\
& US & 40 & -0.3 & -0.5 & -0.6 \\
Peak of output decline (\%) & Euro Area & -0.3 & -0.3 & -0.5 & -0.6 \\
& US & -0.2 & -1.3 & -2.0 \\
$\begin{array}{l}\text { Transition costs (\% p.a.) computed as } \\
\text { cumulative output loss over the }\end{array}$ & Euro Area & -0.6 & -1.0 & -1.5 & -2.1 \\
simulation period & US & -0.4 & -1.0 & & \\
\hline
\end{tabular}

Note: 1 p.p. increase in capital requirements over a two-year horizon Source: Roger and Vlcek (2011)

\section{DAta AND Methodology}

\section{A. Data}

We collect balance sheet and income statements of the five largest banks in the EU emerging-market countries in 2008-2014. The data are picked up from Bankscope for Bulgaria (BLG), the Czech Republic (CZE), Hungary (HUN), Latvia (LAT), Lithuania (LIT), Poland (POL), Romania (ROM), Slovakia (SVK), and Slovenia (SLO). ${ }^{5}$ Banks are chosen based on their asset-size rank reported in Bankscope. We exclude banks for which accounting data are not available over the entire period. As a result, our sample reduces to 38 commercial banks, out of 45 . We collected unconsolidated balance sheets and income statements for these banks. If the unconsolidated accounting data are not available, the consolidated balance sheets are used. Definition of capital is based on Basel II standards over the whole period examined in the paper. Computing CAR, the risk weighted assets as reported by Banscope are used. ${ }^{6}$

\section{The five largest banks in each country represent more than one half of banking sector} assets. Most of banks are subsidiaries of foreign banks from advanced countries. See Table 2 for the five largest banks' share of total assets as reported by the ECB. The banks selected for Bulgaria and Poland hold less but close to 50 percent of total bank assets and thus they represent the bulk of the banking sector. Most of the banks in our sample are subsidiaries of foreign banks. The remaining banks are either owned by the state, the case of the banks in Slovenia, or have foreign owners.

\footnotetext{
${ }^{5}$ Estonia is excluded from the sample because the data does not cover the period of interest.

${ }^{6}$ Banks can use either standardized or Internal Rating Based system, which is subject to regulatory approval.
} 
Table 2: Share of largest banks on total banking sector assets

\begin{tabular}{lccc}
\hline \multicolumn{1}{c}{ Country } & $\begin{array}{c}\text { Share of five largest } \\
\text { banks on total assets* } \\
\text { in 2013, percent }\end{array}$ & $\begin{array}{c}\text { Number of banks in } \\
\text { our analysis }\end{array}$ & $\begin{array}{c}\text { Number of foreign } \\
\text { bank subsidiaries }\end{array}$ \\
\hline Bulgaria (BLG) & 49.9 & 4 & 3 \\
Czech Republic (CZE) & 62.8 & 5 & 5 \\
Hungary (HUN) & 51.9 & 4 & 3 \\
Latvia (LAT) & 64.1 & 4 & 4 \\
Lithuania (LIT) & 87.1 & 4 & 3 \\
Poland (POL) & 45.2 & 5 & 4 \\
Romania (ROM) & 54.4 & 5 & 4 \\
Slovakia (SVK) & 70.3 & 4 & 0 \\
Slovenia (SLO) & 57.1 & 3 & \\
\hline & & & \\
* ECB report of MFI, ** State owned & & &
\end{tabular}

\section{B. Methodology}

We first identify bank strategies for achieving higher capital adequacy ratios. Based on the bank strategies, we judge the macroeconomic costs of meeting higher capital requirements qualitatively by ranking the strategies. In this respect, we rely on findings of Roger and Vlcek (2011), which are reported in Table 1. Instead of considering the absolute value of output losses as estimated by the paper, we rank identified adjustment strategies. In this respect, we consider a cut of dividend payments or an issue of new capital as the most benign strategies, if measured by macroeconomic costs. On the opposite side of the spectrum, we consider a decline of assets and lending as incurring the highest macroeconomic costs in line with the findings of Roger and Vlcek (2011). ${ }^{7}$

In order to achieve higher capital ratios, banks can pick up one of the strategies below or combine them. The ordering of strategies aims to reflect varying degrees of macroeconomic costs, going from the most benign to strategy considered to the most costly. Banks' adjustment strategies can be as follows:

1) Issue new equity, implying a dilution of existing shareholder rights ${ }^{8}$

2) Reducing dividend payments and/or return on equity;

3) Increase retained earnings by:

a) Increasing net income by raising operating efficiency while keeping spreads and dividends unchanged;

b) Increasing net income through average lending margins, while keeping dividends unchanged;

4) Reduce risk-weighted assets by:

\footnotetext{
${ }^{7}$ However, one might argue that a lower rate of lending can be beneficial if the economy faces excessive lending for non-productive use and capital is misallocated.

${ }^{8}$ The value for existing shareholders is diluted if the new stock is issued for less than intrinsic, fair value of the corporation.
} 
a) Shifting the composition of loan portfolios towards assets perceived by regulators as less risky (for example government bonds ${ }^{9}$ );

b) Cutting the overall size of the loan portfolios or slowing their growths

To identify the above mentioned strategies of adjustment, we decompose changes in capital ratios following the approach of Cohen and Scatigna (2014). The decomposition relies on balance sheet and income statements and accounting identities to link stocks and flows. First, it starts with the accounting identity that bank capital in time $t$ is equal to bank capital in time t-1 adjusted by new capital and retained earnings, see Annex A for details. Retained earnings are the sum of net income adjusted by dividends. Dividing this identity by risk weighted assets (RWA) and after log-linearization, Cohen and Scatigna (2014) get:

$$
\frac{B_{t}}{R W A_{t}}-\frac{B_{t-1}}{R W A_{t-1}}=S\left[\ln \left(1+\frac{B_{t}^{N I}}{B_{t-1}}+\frac{\text { Income }}{B_{t-1}}-\frac{D i v_{t}}{B_{t-1}}\right)-\ln \left(\frac{\frac{R W A_{t}}{T A_{t}}}{\frac{R W A_{t-1}}{T A_{t-1}}}\right)-\ln \left(\frac{T A_{t}}{T A_{t-1}}\right)\right]
$$

$\begin{array}{cl}\begin{array}{c}\text { Riskiness of } \\ \text { assets }\end{array} & \begin{array}{l}\text { Size of the balance } \\ \text { sheet }\end{array}\end{array}$

where $\mathrm{B}$ is capital, $\mathrm{B}^{\mathrm{NI}}$ is newly issued capital (approximated later by newly issued equity), $R W A$ is risk weighted assets, $T A$ total assets, Income is net income plus other comprehensive income, and Div are paid dividends. $S$ is a scaling factor as a consequence of the linearization of the budget constraint identity. ${ }^{10}$ The numerator of the relationship above captures the accumulation of capital through retained earnings. The first term on the left hand side of the above equation captures the effects of retained earnings and newly issued capital. The second term measures changes in the riskiness of bank assets and the third one quantifies the effect of balance sheet expansion.

We decompose accumulated capital part into subcomponents in order to inspect whether banks raised their comprehensive income, issued new capital, or reduced dividend payments. We employ newly-issued equity as a proxy of newly issued capital to break down accumulated capital. ${ }^{11}$ Following the accounting identity, we get:

$$
B_{t}=B_{t-1}+B_{t}^{N I}+N I_{t}-D i v_{t}+R e v_{t},
$$

\footnotetext{
${ }^{9}$ The issue of sovereign exposures and its regulation are discussed in European Systemic Risk Board (2015).

${ }^{10}$ See Annex A for details.

${ }^{11}$ Equity might be subject to deductions to be accounted as capital by the regulatory authority. In fact, the regulatory authority decides about what is going to be considered as capital.
} 
where $B$ stands for equity (book value), $B^{N I}$, is the newly-issued equity, $N I$ is net income (comprehensive), Div are dividend payments, and $R e v$ are revaluations. Finally, to distinguish among strategies $1-4$ we decompose net income as follows:

$$
N I_{t}=N I I_{t}+N O I_{t}+\operatorname{TaxRev}_{t}
$$

Here NII stands for net interest income, NOI is net operating income (net non-interest income), and TaxRev is other net income, mainly taxes paid and revaluations. To understand the issue better, the sources of changes in net interest income, we also look at volumes of loans and lending spreads below.

We do not analyze reasons for the choice of adjustment strategy; in this regard, our paper is descriptive. We also focus primarily on capital regulation and do not evaluate the other parts of regulatory reforms related to liquidity standards.

\section{Capital Adequacy Ratio Dynamics and Adjustment Strategies}

The share of capital to risk weighted assets increased in all countries. However, capital ratios differ across countries in levels as well as in dynamics. Capital ratios increased from the level of around 10-15 percent in 2008 to about 15-25 percent in 2014, Figure 1. This implies an increase by almost $1 \mathrm{pp}$ on average per year. In fact, the highest increases are experienced by countries with banking sector problems or crisis as in Latvia, Lithuania, and Slovenia. The increase is not necessarily motivated by higher regulatory requirements but it might also reflect the need to de-risk the banks' balance sheets during the recession and other macroeconomic developments. The differences in levels of capital ratios mirror the riskiness of national banking systems along with systemic and conservation buffers, set at the discretion of local regulatory authorities.

The rising share of capital to risk weighted assets in 2008--2014 also mirrors effects other than Basel III. In fact, the Basel III phase in period started in 2013. Nevertheless, the reform and its parameters were announced in advance to give commercial banks enough of room to meet new regulatory requirements. As the discussion about tighter regulatory requirements started during the world financial crisis, we tend to consider to examined period as a good proxy to assess the effects of Basel III. Surely, other factors as the financial crisis, interbank market uncertainty, and search for quality might play a role motivating banks to raise their capital ratios. 
Fig. 1: Capital to Risk Weighted Assets (percent, Basel II definition) -

Weighted average (by their asset size) of five largest banks

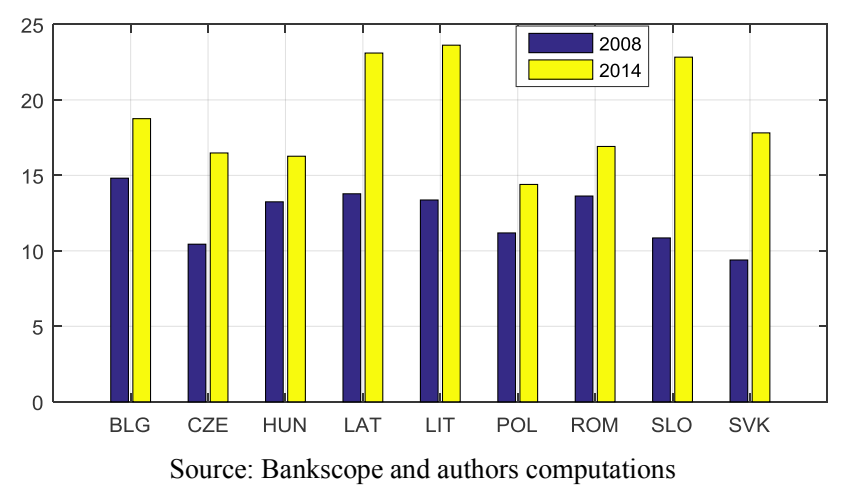

We analyze changes in capital adequacy ratios (CAR). Namely, we decompose CAR into the accumulation of capital and changes in risk weights and total assets. To determine strategies used by the banks, we further break down accumulated capital into newly issued equity, retained earnings (as net income adjusted by dividends), and revaluation. Furthermore, decomposition of net income into net interest income, other income, other expenses, and taxes help us to judge sources of retained earnings. In order to assess if increased operating income is due to larger volumes or spreads, we also look at their evolution. Based on identified strategies we determine the macroeconomic costs and show that the costs vary with the performance of the banking sector.

\section{A. CAR decomposition}

We decompose changes of CAR into accumulation of capital and changes in risk weights and total assets, see Table 3 . We report contributions of the above mentioned components to total change in ratio of capital to risk weighted assets. Contributions are determined based on equation (1) and represent ceteris paribus contributions. Namely, the column Accumulation of capital determines the change of CAR assuming that total assets and risk weights are unchanged. The same holds for other contributions, the ratio of risk weighted assets to total assets and total asset growth.

Banks reduced the risk weight of their portfolios in all countries, as measured by the change in the ratio of risk weighted assets to total assets. A positive value means a decline in the riskiness with a positive effect on CARs. As the riskiness of banks' balance sheets declined on average in all countries, see column RWA to TA in Table 3, Strategy $4 a$ was partly used by all banking sectors in our sample. The ratio of risk weighted assets to total assets declined despite an increase in loans in total assets as discussed later, see Figure 3. 
Table 3: Decomposition of capital to RWA ratios

\begin{tabular}{|c|c|c|c|c|c|c|}
\hline & \multirow{2}{*}{$\begin{array}{c}\text { Capital to } \\
\text { RWA in } 2008\end{array}$} & \multirow{2}{*}{$\begin{array}{c}\text { Capital to } \\
\text { RWA in } 2014\end{array}$} & \multirow{2}{*}{$\begin{array}{l}\text { Change in } \\
\text { capital ratio }\end{array}$} & \multicolumn{3}{|c|}{ Contributions } \\
\hline & & & & $\begin{array}{l}\text { Accumulation of } \\
\text { capital }\end{array}$ & RWA to TA & $\begin{array}{c}\text { Total Assets } \\
\text { (TA) }\end{array}$ \\
\hline BLG & 14.8 & 18.8 & 4.0 & 5.4 & 4.1 & -5.5 \\
\hline CZE & 10.4 & 16.5 & 6.1 & 6.9 & 2.5 & -3.3 \\
\hline HUN & 13.2 & 16.3 & 3.1 & 0.6 & 2.8 & -0.3 \\
\hline LAT & 13.8 & 23.1 & 9.3 & 5.1 & 6.1 & -1.9 \\
\hline LIT & 13.4 & 23.6 & 10.2 & 4.1 & 6.2 & -0.1 \\
\hline POL & 11.1 & 14.4 & 3.3 & 8.0 & 1.4 & -6.1 \\
\hline ROM & 13.6 & 16.9 & 3.3 & 1.7 & 4.5 & -2.9 \\
\hline SLO & 10.9 & 22.8 & 11.9 & -3.0 & 8.2 & 6.7 \\
\hline SVK & 9.4 & 17.8 & 8.4 & 8.1 & 1.3 & -1.0 \\
\hline
\end{tabular}

Note: The third column represents change in capital ratios over the examined period and it equals to the second minus the first column. The remaining columns provide decomposition of the third column, the change in capital to risk weighted ratios, in percentage points. All contributions are a cumulative sum over the horizon.

Source: Bankscope and authors’ computations

Most of countries experienced rising CARs while their banks' balance sheets expanded. However, there also countries in which banks shrank their balance sheets, helping them to raise CARs, or balance sheet growth was low. The first group is represented by BLG, CZE, LAT, POL, ROM and SVK. Increasing balance sheets in these countries, ceteris paribus, would reduce the capital adequacy ratios. As a result, the contribution to CAR growth is negative, see Table 3 column Total Assets. In contrast, the balance sheets of banks declined in SLO and remained unchanged in HUN and LIT. ${ }^{12}$ Therefore, the most costly Strategy $4 b$ helped increase CARs in these countries. However, it cannot be proven that the reduction in bank assets was a response to tighter regulatory measures. It may also mirror country fundamentals, structural factors, and the business cycle position. However, regardless of the reason, the reduction of assets is the costliest strategy of adjustment from a macroeconomic point of view.

The accumulation of capital was the main source of improvement of CARs in countries with rising total assets. The contribution of capital accumulation is twice as important as the reduction in the riskiness of assets in most countries with growing banking sector assets, see Table 3. In countries where banks experienced declining total assets, the reduction in the riskiness of assets and not capital accumulation is the main factor behind the higher CARs.

\section{B. Decomposition of equity accumulation}

Profitable banking sectors used higher retained earnings to raise CARs against the backdrop of enlarging balance sheets and stable dividend payout ratios. Table 4 decomposes accumulated capital, approximated by equity, into net income, dividend payout, newly issued equity, and revaluations, as a part of comprehensive income. Equity, as well as

\footnotetext{
${ }^{12}$ Annex B reports shares of loans and assets on GDP for the set of countries and banks in our analysis. It shows that the share of assets and loans on GDP declined only in HUN, LIT, and SLO.
} 
all the other measures in Table 4, are normalized by RWA in 2008. The table suggests that banks with growing balance sheets accumulated equity mainly using retained earnings. Only about one third of the increase in equity came from newly issued equity. It implies that banks seek to avoid a decline in their assets and they employ retained earnings rather than the issue of new equity. Hence, banks followed Strategy 1 only if there was no other option to fulfill the new requirements.

Banks seem to be reluctant to reduce dividends. Hence, they seek to keep the dividend payout ratio stable and thus they do not tend to follow Strategy 2. Even the banking sectors experiencing losses on average over the period paid dividends. Hence, the losses were covered by issuing new equity instead of retained earnings and reserves. This aspect of bank behavior is at least partly attributable to their parent-child relationship. Any cut in dividends reduced payments to parent banks.

Table 4: Equity growth decomposition (share on 2008's RWA)

\begin{tabular}{|c|c|c|c|c|c|c|c|}
\hline & \multirow{2}{*}{$\begin{array}{l}\text { Equity in } 2008 \\
\text { to RWA_base }\end{array}$} & \multirow{2}{*}{$\begin{array}{l}\text { Equity in } 2014 \\
\text { to RWA_base }\end{array}$} & \multirow{2}{*}{$\begin{array}{l}\text { Change in } \\
\text { Equity to } \\
\text { RWA_base }\end{array}$} & \multicolumn{4}{|c|}{ Contributions } \\
\hline & & & & Net Income & of Dividends & $\begin{array}{l}\text { Newly } \\
\text { issued } \\
\text { Equity }\end{array}$ & Revaluations \\
\hline BLG & 14.2 & 22.5 & 8.3 & 11.1 & -5.4 & 2.8 & -0.2 \\
\hline $\mathrm{CZE}$ & 14.1 & 24.8 & 10.7 & 18.6 & -11.8 & 2.0 & 1.9 \\
\hline HUN & 11.8 & 13.7 & 1.9 & -0.1 & -2.3 & 5.0 & -0.7 \\
\hline LAT & 13.0 & 18.5 & 5.6 & 2.3 & -2.9 & 6.0 & 0.2 \\
\hline LIT & 12.9 & 19.1 & 6.2 & 0.2 & -0.3 & 6.2 & 0.1 \\
\hline POL & 12.1 & 25.6 & 13.5 & 15.5 & -7.7 & 4.2 & 1.5 \\
\hline ROM & 12.7 & 16.3 & 3.6 & 3.0 & -1.2 & 1.2 & 0.6 \\
\hline SLO & 8.9 & 10.0 & 1.1 & -17.9 & -0.1 & 18.7 & 0.4 \\
\hline SVK & 11.0 & 19.6 & 8.6 & 11.5 & -6.9 & 3.6 & 0.4 \\
\hline
\end{tabular}

Note: RWA_base denotes risk weighted assets in 2008. It is used as the denominator in this table. Source: Bankscope and authors' computations

Less profitable banks or banks facing losses for several consecutive years rely mainly on newly issued equity. These banks also reduced or did not enlarge their balance sheets. SLO and LIT are examples along with HUN. Newly issued equities in such a case came mainly from public sources as governments (SLO case) or they were provided by parent companies.

\section{Decomposition of Net Income}

Most EU emerging market countries experienced profitable banking sectors. However, the return on banks' assets in emerging market economies has gradually declined, see Figure 2. First, there is a convergence in this respect towards advanced countries' returns due to competition and globalization, see Annex D. Measured by net income on assets or by return on assets, the profitability had been above the average of advanced countries. However, a few banking sectors, namely those in Hungary, Latvia, Lithuania, and Slovenia faced issues with adverse effects on their profitability. ${ }^{13}$ Second, the negative impact from net

${ }^{13}$ A bank levy has been introduced in Hungary since 2010. 
other income (mainly taxes and revaluation) more than doubled in most of the countries in 2008 - 2014, dampening the net income on assets. The negative effects of higher net other income on net income were only partly offset by net interest and non-interest income.

Most of the examined banking sectors reduced operating costs to support the return on assets. Banking sectors reduced negative net operating income with the exception of HUN, SLO, and SVK. ${ }^{14}$ This would favor Strategy $3 a$ suggesting that banks were able to boost profitability by higher efficiency.

Evidence on net interest income is mixed. Net interest income increased above the precrisis period in CZE, HUN, ROM, and SVK, see Figure 2. In all other countries, it declined compared to the pre-crisis period. Net interest income is determined by the volume of loans and deposits and by their interest rate spread.

Figure 2: Income shares on total assets (average per period in percent)
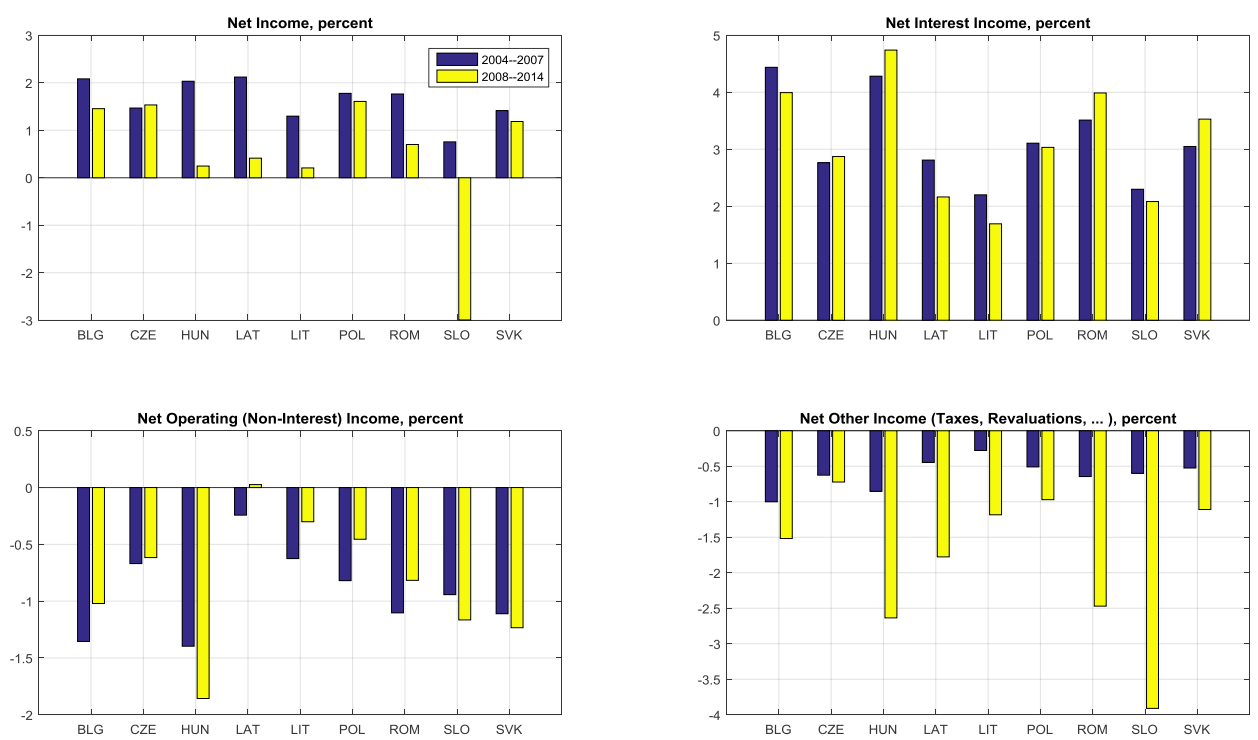

Source: Bankscope and authors' computations

Banks in the examined countries did not reduce the share of loans in total assets, see Figure 3. All banks raised the share of loans in assets with the exception of HUN and LAT banks. At the same time, about half of banking sectors covered in our study also raised the loans to deposits ratios. Both factors helped banks to boost or maintain the level of net interest income on assets relative to the pre-crisis period. Furthermore, the higher share of loans in total assets and higher loans to deposit ratios did not adversely affect the riskiness of banks' assets as it was shown in the previous subsection.

\footnotetext{
14 These banking sectors also faced deepening of negative other net income.
} 
Figure 3: Shares of loans
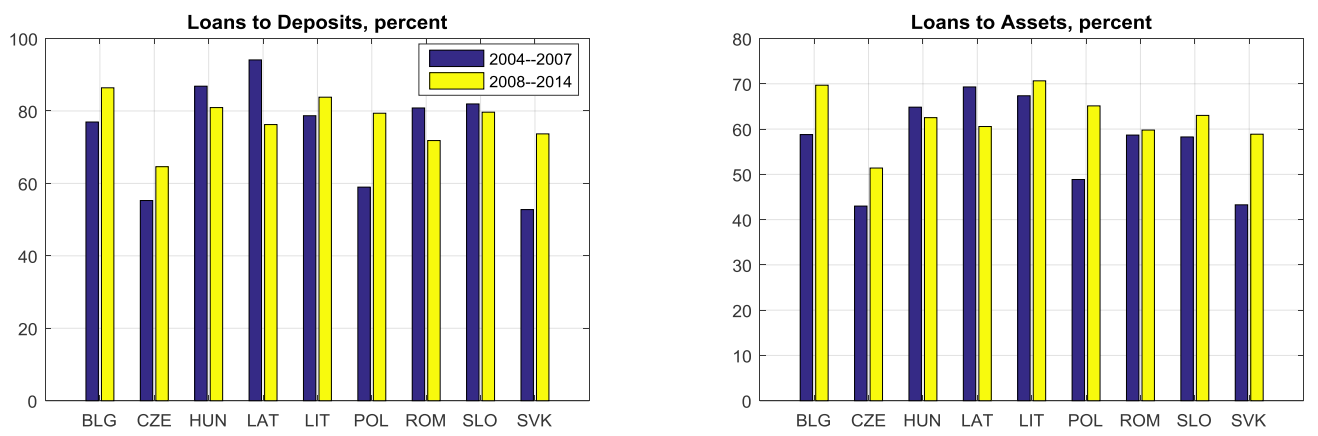

Source: Bankscope and authors' computation

We do not observe any increase of lending spreads in 2008 - 2014 above the pre-crisis average, Figure 4. In fact with exception of countries experiencing banking sector issues such as HUN and SLO, all banking sectors reduced lending spreads compared to the precrisis level. Interest rate spreads below the pre-crisis average might suggest that banks did not used Strategy $3 b$.

Figure 4: Implicit lending rate spreads (average per period in basis points)

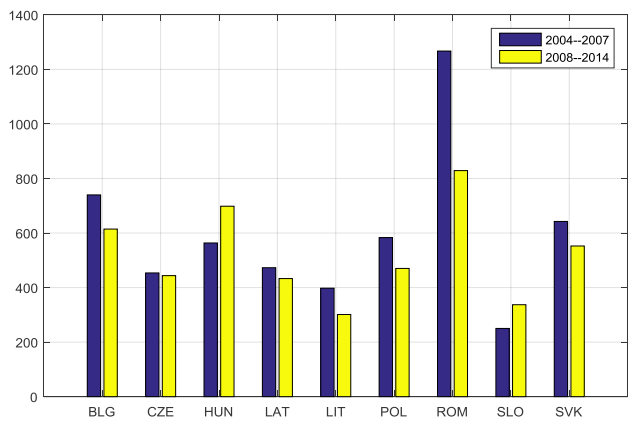

Note: Implicit lending spreads are computed as the difference between implicit interest rate on loans and implicit interest rate on deposits. The implicit interest rate on loans is computed from interest revenues from loans divided by the amount of loans. Similarly, we derive the implicit interest rate on deposits.

Source: Bankscope and authors' computation 


\section{Conclusion}

The threat that banks would notably reduce their lending in response to higher capital requirements does not seem to have materialized in Emerging Europe. Banks used not one but a combination of strategies to raise capital levels, ranging from retained earnings to new equity issuance. Banking sectors in these countries also reduced their riskiness, as measured through risk weighted assets to total assets.

Our analysis and cross-country comparison suggest that profitable banking sectors tend to use the most benign ways, from a macroeconomic point of view, to increase CARs. Namely, the banks use mainly retained earnings, while paying dividends and expanding balance sheets. This is in line with mainstream economic theory, which considers the cost of a gradual increase of capital requirements as marginal, in reference to ModiglianiMiller arbitrage conditions. In contrast, struggling banking sectors tended to rely on newly issued equity and a reduction of riskiness of their asset portfolios. Frequently, they also reduced the magnitude of their balance sheets. 


\section{References}

Admati, A., P.M. DeMarzo, M. Hellwig, and P. Pfleiderer, 2013: Fallacies, Irrelevant Facts, and Myths in the Discussion of Capital Regulation: Why Bank Equity is Not Socially Expensive, GSB Stanford, mimeo.

Admati, A. and M. Hellwig, 2013: The Bankers' New Clothes: What's Wrong with Banking and What to Do about It, Princeton University Press.

Andrle, M., Kumhof, M., Laxton, D. and D. Muir, 2015: "Banks in Global Integrated Monetary and Fiscal Model”, IMF Working Paper 55/15.

Basel Committee on Banking Supervision, 2010: “An Assessment of the Long-term Economic Impact of Stronger Capital and Liquidity Requirements", Retrieved from BIS website: http://www.bis.org/publ/bcbs173.pdf

Cohen, B. H., 2013. "How Have Banks Adjusted to Higher Capital Requirements?” in BIS Quarterly Review, September 2013. BIS.

Cohen, B. H. and M. Scatigna, 2014. "Banks and Capital Requirements: Channels of Adjustment.” BIS Working Paper No. 443, BIS.

European Systemic Risk Board, 2015. "ESRB report on the regulatory treatment of sovereign exposures," ESRB.

Kashyap, A.K., J.C. Stein and S. Hanson, 2010: "An Analysis of the Impact of 'Substantially Heightened' Capital Requirements on Large Financial Institutions", University of Chicago, Booth School of Business, mimeograph.

Macroeconomic Assessment Group, 2010: "Assessing the Macroeconomic Impact of the Transition to Stronger Capital and Liquidity Requirements: Final Report”. Retrieved from BIS website: http://www.bis.org/publ/othp12.pdf.

Mandel, M. and V. Tomšík , 2015: "Dynamika a rovnováha úspor, investic a úvěru v hospodářském cycklu: příklad České republiky“, Politická Ekonomie 1, p.32—56.

Miles, D., J. Yang and G. Marcheggiano, 2013. "Optimal Bank Capital," Economic Journal, Royal Economic Society, vol. 123(567), pages 1-37, 03.

Miller, M.H. and F. Modigliani, 1961: „Dividend Policy, Growth, and the Valuation of Shares“, Journal of Business, 34, 411-433.

Modigliani, F. and M.H. Miller, 1958: „The Cost of Capital, Corporation Finance and the Theory of Investment“", American Economic Review, 48(3), 261-297. 
Modigliani, F. and M.H. Miller, 1963: „Corporate income taxes and the cost of capital: a correction“, American Economic Review, 53(3), 433-443.

Roger, S. and J. Vlcek, 2011. "Macroeconomic Costs of Higher Capital and Liquidity Requirements." IMF Working Paper 11/103. International Monetary Fund.

Stiglitz, J., 1973: "Taxation, Corporate Financial Policy, and the Cost of Capital", Journal of Public Economics, 2, 1-34. 


\section{A. Appendix: Capital Accumulation Decomposition}

We start from the identity for capital accumulation:

$$
B_{t}=B_{t-1}+B_{t}^{N I}+\text { Income }_{t}-\text { Div }_{t}
$$

Here $B$ is capital, $B^{N I}$ is newly issued capital, Income is a sum of net income and other income, and Div are dividend payments. Dividing both sides by $B_{t-1}$ and by risk weighted assets $R W A$, we get:

$$
\frac{B_{t} / R W A_{t}}{B_{t-1} / R W A_{t-1}}=\frac{\left(1+\frac{B_{t}^{N I}}{B_{t-1}}+\frac{\text { Income }_{t}}{B_{t-1}}-\frac{\text { Div }_{t}}{B_{t-1}}\right)}{\frac{R W A_{t} / T A_{t}}{R W A_{t-1}} / T A_{t-1}} \frac{T A_{t-1}}{R W}
$$

After log-linearization we obtain:

$$
\frac{B_{t}}{R W A_{t}}-\frac{B_{t-1}}{R W A_{t-1}}=S\left[\ln \left(1+\frac{B_{t}^{N I}}{B_{t-1}}+\frac{\text { Income }}{B_{t-1}}-\frac{D i v_{t}}{B_{t-1}}\right)-\ln \left(\frac{\frac{R W A_{t}}{T A_{t}}}{\frac{R W A_{t-1}}{T A_{t-1}}}\right)-\ln \left(\frac{T A_{t}}{T A_{t-1}}\right)\right]
$$

Where $S$, as a scaling factor, equals to:

$$
S=\frac{\left(\frac{B_{t}}{R W A_{t}}-\frac{B_{t-1}}{R W A_{t-1}}\right)}{\ln \left(\frac{\frac{B_{t}}{R W A_{t}}}{\frac{B_{t-1}}{R W A_{t-1}}}\right)}
$$




\section{B. Appendix: Stylized Facts}

Banks in EU emerging markets are highly profitable despite the real economy slowdown in the wake of the recent financial crisis, Figure B1. Banking sectors in these countries reached the highest average return on assets (RoA) in the EU. Only countries facing banking sector issues as Latvia, Slovenia, Hungary, and Lithuania either experienced losses or low RoA.

Figure B1: Average return on assets in EU countries in 2008-2014 (percent p.a.)

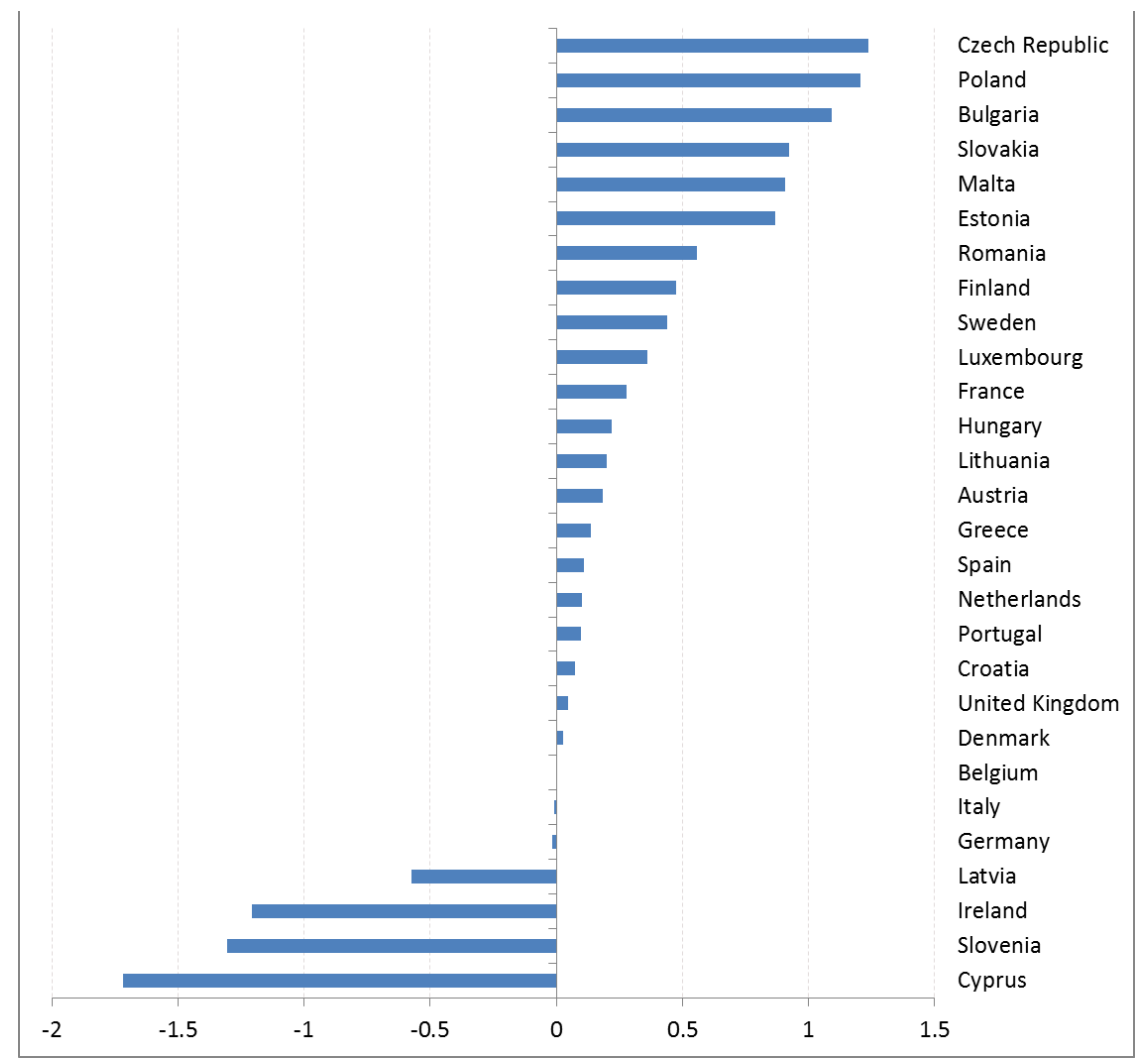

Source: ECB Statistical Data Warehouse and authors' computations

While the analyses presented in the paper are based on bank data aggregated by country, individual banks might differ in profitability, capital adequacy, and balance sheet structure. Figures B3, B4, and B5 show the distributions of CAR, RoE, and loans as a share of assets using bank data abstracting from countries. Boxplots are used to characterize the distribution of the data. At each point of time there is a box with a tick line. The box captures quartiles and the tick line is the median. Vertical lines coming out from the box depict lower and higher extreme values while points/dots are outliers. The data presented in figures suggest a relatively narrow distribution of CARs across banks with almost no downward outliers. Similarly, the share of loans as a share of total assets is relatively homogenous among banks. In contrast, RoE varies across banks from 0 to 20 . 
Figure B3: Capital Adequacy Ratio (CAR, \%)

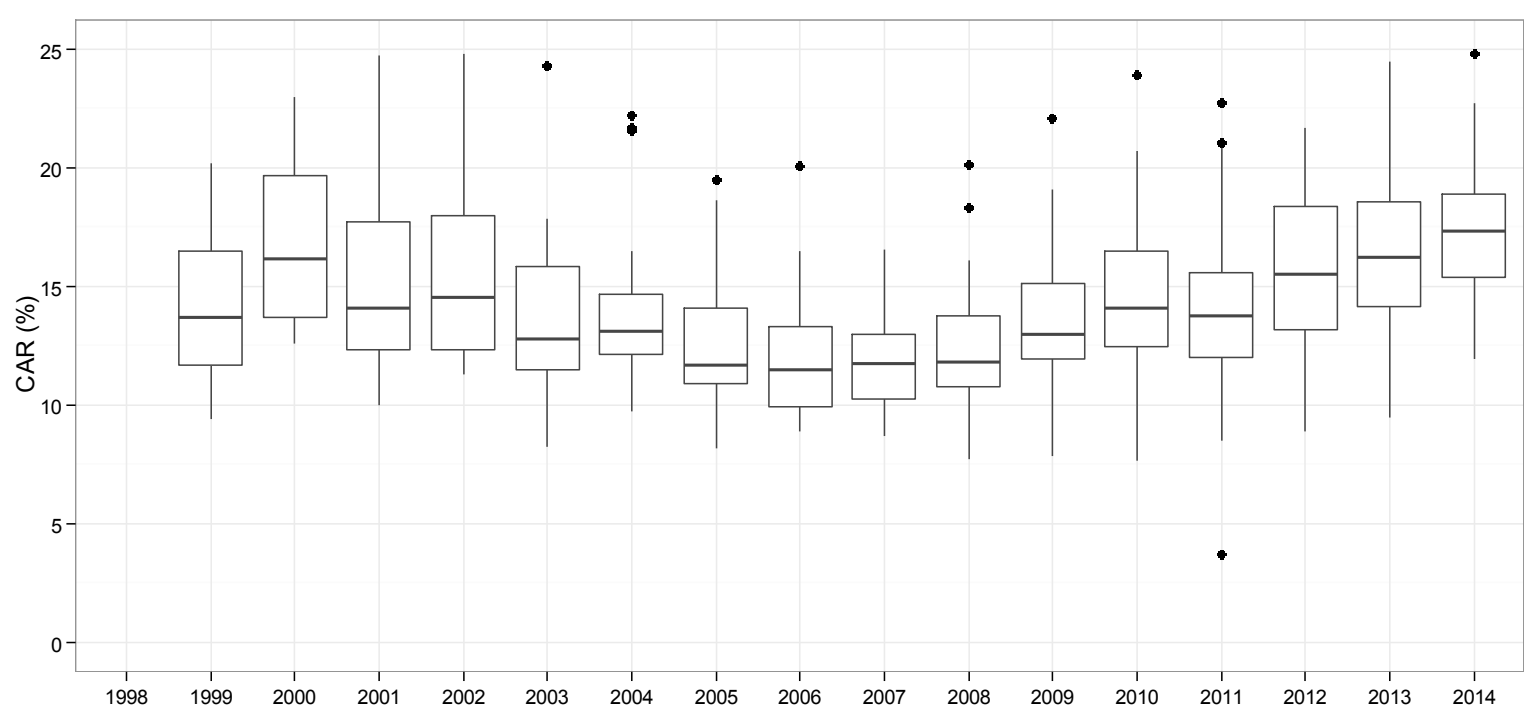

Figure B4: Return on Equity (\%)

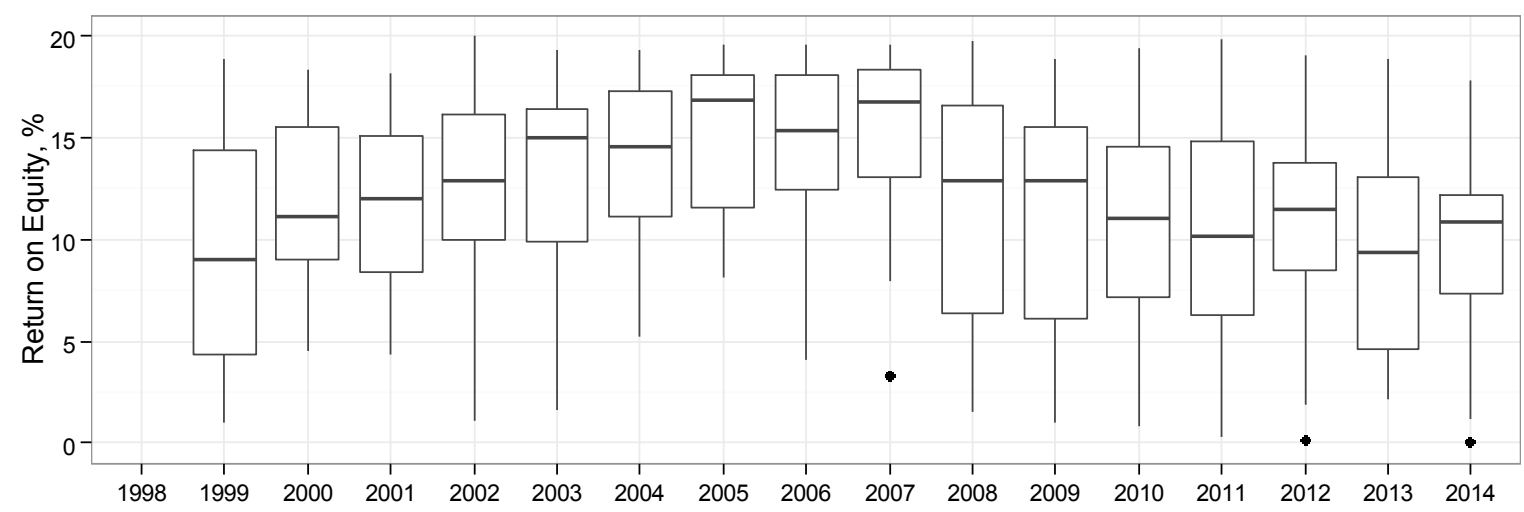

Figure B5: Loans Share of Assets

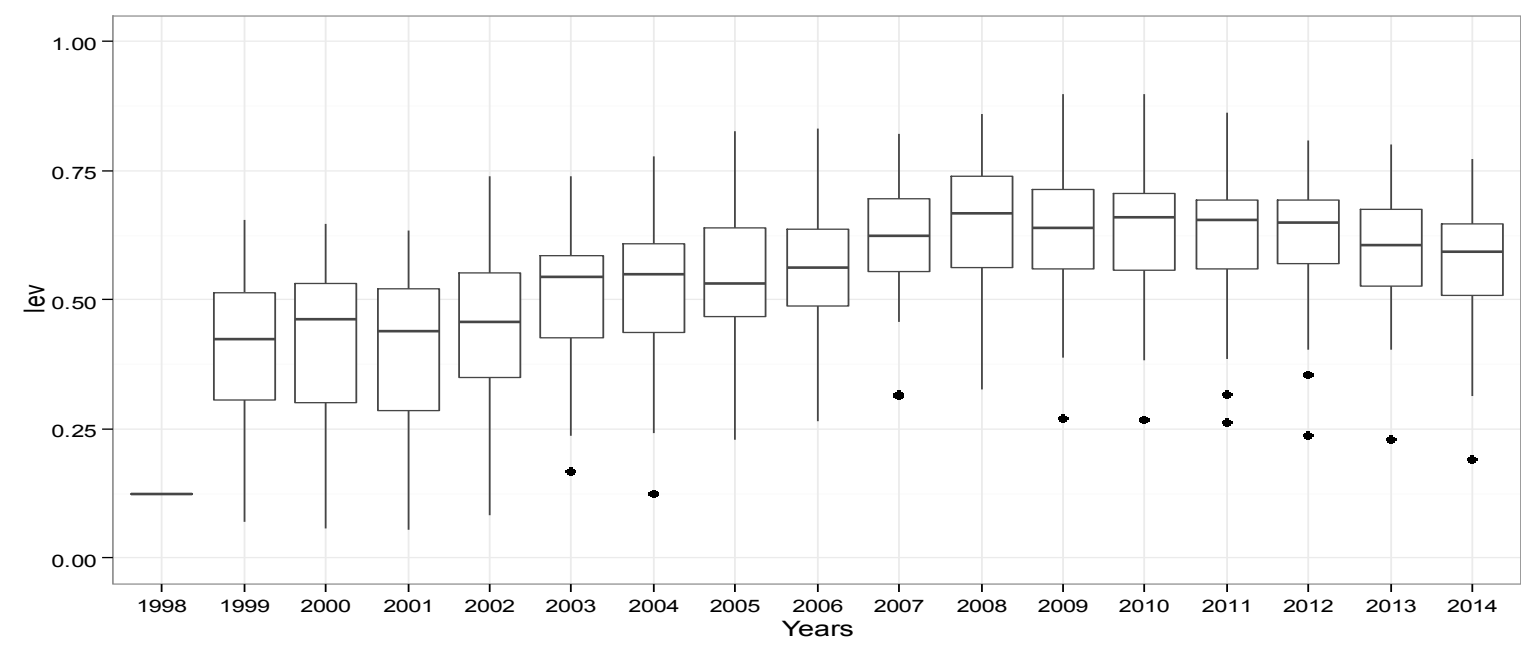


The banking sectors in HUN, LIT and SLO deleveraged measured by shares of loans and assets in GDP, Figure B6. In contrast, the shares continued to grow in remaining countries.

Figure B6: Assets and loans on GDP - only banks used in the paper, percent
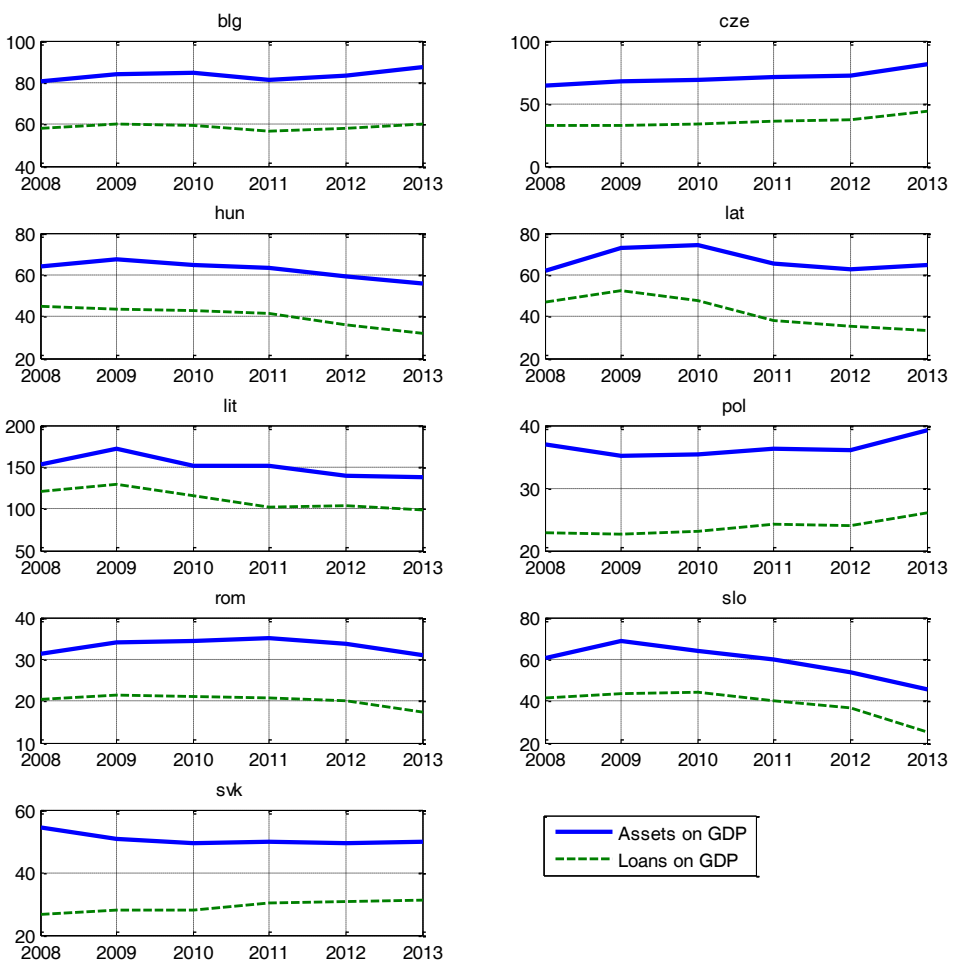

Source: Bankscope, ECB, and authors' computations 


\section{Appendix: The Leverage Arithmetic}

The arithmetic of leverage is straightforward, but often goes under-appreciated. Two simple issues are worth mentioning to get a quantitative grasp of the change in banks' leverage. First, even with a strong departure from the Modigliani-Miller Theorem (MMT), when the return on equity does not change, the weighted-average cost of capital does not increase in a dramatic manner. And second, the fact that banks are leveraged allows profitable banks to decrease their leverage quickly, should they choose so.

\section{1) Weighted Average Cost of Capital (WACC) under deviation from MMT}

The weighted-average cost of capital, WACC, is given by

$$
\mathrm{WACC}=\mathrm{RoE} * \mathrm{E} /(\mathrm{Debt}+\mathrm{E})+\mathrm{RoD} *(1-\mathrm{E} /(\mathrm{Debt}+\mathrm{E}))
$$

where RoE is the return on equity, E stands for equity and RoD is the return on debt. The following illustrative calculation assumes that the return on debt is $5 \%$ and the return on equity is $15 \%$. Under the extreme case of deviation from MMT, assuming that the return on equity does not react to leverage, WACC increases. In this specific case, WACC profile looks as follows:

\begin{tabular}{|c|c|c|c|c|c|c|c|c|c|c|c|c|c|}
\hline R_Equity & 0.15 & & & & & & & & & & & & \\
\hline R_Debt & 0.05 & & & & & & & & & & & & \\
\hline$E /(D+E)$ & 0.02 & 0.03 & 0.05 & 0.1 & 0.15 & 0.2 & 0.25 & 0.3 & 0.35 & 0.4 & 0.45 & 0.5 & 0.55 \\
\hline WACC & 0.052 & 0.053 & 0.055 & 0.06 & 0.065 & 0.07 & 0.075 & 0.08 & 0.085 & 0.09 & 0.095 & 0.1 & 0.105 \\
\hline
\end{tabular}

The table above suggests that increasing the share of equity in total liabilities from $10 \%$ to $20 \%$ raises WACC by 1 percentage point. And going from 3\% to 5\% increases WACC by 20 basis points. Without the deviation from MMT, the rising share of equity is offset by lower a return on equity, keeping WACC constant. Empirical estimates, see e.g. Kashyap and others (2010) and Miles and others (2012), suggest that this MMT “offsetting power" is about one half. Hence, the actual estimate is roughly one half of the effect if MMT does not hold.

\section{2) Leverage hurts in bad times but helps in good times}

It is clear that leverage can hurt in bad times; the purpose of leverage is to boost profitability in good times. Starting from a sizeable degree of leverage, profitable banks may decrease their leverage in relative short period of time, depending on the use of profits. The banks can either significantly lengthen the maturity structure of their balance sheet and keep the leverage unchanged, or lower the leverage.

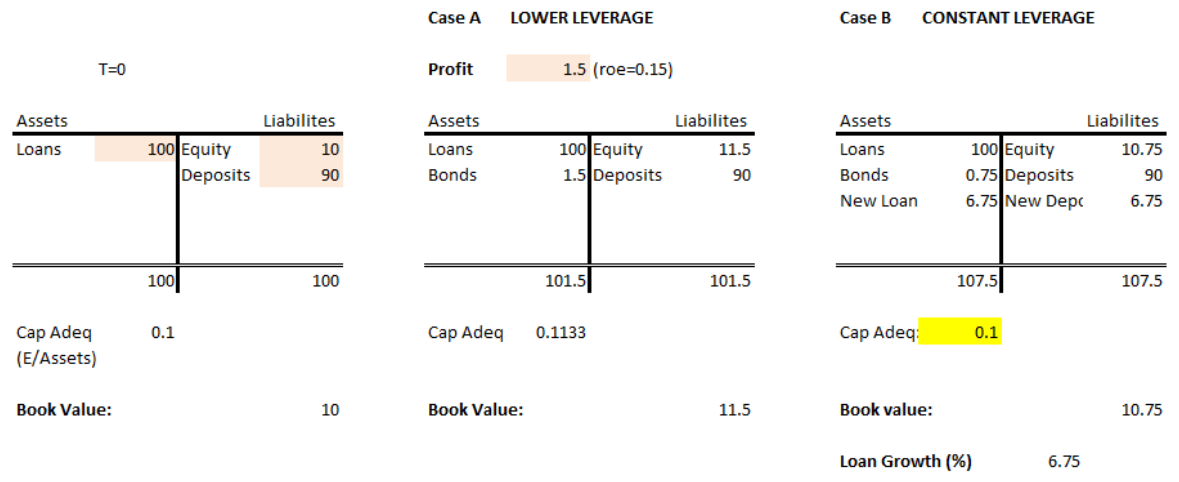

